\title{
Dokumentasi Tari Tradisional
}

\author{
Budi Astuti $^{1}$ \\ Jurusan Tari, Fakultas Seni Pertunjukan, Institut Seni Indonesia Yogyakarta
}

\begin{abstract}
ABSTRAK
Documentation of Traditional Dance. Tari merupakan seni sesaat, oleh karena itu dibutuhkan dokumentasi yang baik yang dapat merekam seluruh gerak dan aktivitas yang menyeluruh, sehingga suatu saat dapat direkonstruksikan kembali. Sistem pendokumentasian secara tertulis atau pencatatan tari telah dilakukan sejak jaman dahulu. Sistem pencatatan tari sebagai salah satu cara mendokumentasikan tari masih dilakukan hingga sekarang. Namun demikian sistem pencatatan tari yang dilakukan oleh seniman satu dengan seniman lainnya atau daerah satu dengan daerah lainnya, berbeda-beda. Terlepas dari kekurangan dan kelebihannya, perlu dipikirkan sistem pencatatan tari yang bisa dipahami oleh semua kalangan sehingga bisa dipakai sebagai bahasa komunikasi yang sifatnya universal. Notasi laban bisa dijadikan alternatif sistem pencatatan tari karena mampu merekam detaildetail posisi dan gerak yang paling lembut dan rumit dari setiap bagian tubuh. Kemajuan teknologi memungkinkan sistem pendokumentasian tari melalui perekaman gerak secara visual sangat bermanfaat untuk mendukung dan melengkapi dokumentasi tertulis.
\end{abstract}

Kata Kunci : Dokumentasi Tari, Notasi Laban, Tari Tradisional

\section{Pendahuluan}

Pengertian dokumentasi dalam artian yang luas adalah merupakan produk karya dari kegiatan pengumpulan data, pencatatan dan perekaman tentang suatu peristiwa dan objek-objek yang bertalian dengannya, pengolahan serta penelusuran lebih lanjut atas data/fakta/dokumen tersebut kepada orang yang berkepentingan atasnya (Trimo, 1987:2). Dalam Kamus Besar Bahasa Indonesia disebutkan bahwa dokumentasi adalah: (1) pengumpulan, pemilihan, pengolahan, dan penyimpanan informasi di bidang pengetahuan, (2) pemberian atau pengumpulan bukti-bukti dan keterangan seperti gambar, kutipan, guntingan koran, dan bahan referensi lain (Depdikbud, 1990:211). Dokumentasi berasal dari kata dokumen atau record yang berarti semua hal yang tertulis, tercetak, atau terekam, yang dapat dipakai sebagai bukti atau keterangan. Dengan demikian maka yang dimaksud dokumen sudah tentu semua bahan pustaka baik itu berbentuk tulisan, cetakan, maupun dalam bentuk rekaman lainnya seperti pita suara, video tape, film, slide, micro film, gambar dan lain-lain.

Berbicara tentang dokumentasi jika merujuk pada pengertian di atas tentu sangatlah kompleks. Untuk membatasi penulisan ini maka salah satu objek pendokumentasian di sini akan difokuskan pada tari, dan sistem pendokumentasian yang akan dibicarakan lebih lanjut adalah khusus pendokumentasian melalui pencatatan dan perekaman gerak.

Berawal dari pengalaman bahwa ada suatu kendala dalam dunia tari, jika ingin menengok kembali hasil karya beberapa tahun sebelumnya, atau lebih jauh pada masa pra rekaman gerak, akan dihadapkan pada suatu masalah yang sangat sulit. Meskipun ada dokumentasi berupa catatan gerak, tetapi tanpa dibantu oleh rekaman gerak yang menyeluruh, maka tarian masa lalu itu tidak bisa diketahui seutuhnya (Sedyawati, 1981: 161). Hal itu disebabkan karena sistem pencatatan tari yang dilakukan masih sangat terbatas dan belum bisa mewakili gerak itu secara detail. Sebagai salah satu contoh, seseorang yang ingin mengetahui atau menelusuri bentuk tari istana masa lalu tidak hanya cukup membaca catatan tari yang telah ada, tetapi harus mencari nara sumber yang pernah kenal dengan tari itu untuk menerjemahkan gerak-gerak yang tertulis dalam catatan tari. Apa yang terjadi jika nara sumber yang terkait dengan tari itu tidak ada?, dengan sendirinya catatan tari itu tinggal kenangan belaka. Kalaupun mencoba menginterpretasikan berdasarkan data yang ada, tentu hasilnyapun tidak seperti apa yang diharapkan. Contoh lainnya, pada tahun

1 Alamat korespondensi: Prodi Tari ISI Yogyakarta, jalan Parangtritis KM. 6,5 Sewon, Yogyakarta 55001. Email: budiastuti@ isi.ac.id 
1975 tokoh-tokoh tari dan karawitan istana Yogyakarta berusaha merekonstruksi tari Bedhaya Semang yang diciptakan oleh Sultan Hamengku Buwono II pada alhir abad ke 18. Catatan musik pengiringnya sudah ditemukan, sebagian catatan gerak juga sudah ditemukan, bahkan dilengkapi dengan beberapa foto. Tetapi karena hanya berdasarkan ingatan, sampai sekarang masih banyak bagian yang tidak berhasil direkonstruksi (Soedarsono, 1978: 2). Dengan demikian perlu adanya sistem dokumentasi tari yang baik, agar tidak semakin banyak bentuk tari masa lalu yang hilang tanpa bekas. Bila memungkinkan berbagai macam tari yang telah ditemukan bentuknya yang baku, didokumentasikan dengan baik agar dapat selalu diingat dan dipertunjukkan kembali.

Sistem pendokumentasian secara tertulis atau pencatatan tari telah dilakukan sejak jaman dahulu, terutama dikalangan istana yang bentuk tarinya sudah mapan, dan sistem pencatatan tari sebagai salah satu cara mendokumentasikan tari, masih dilakukan hingga sekarang. Kelemahannya, catatan tari tersebut hanya bisa dipahami dan dimengerti oleh kalangan budaya tertentu saja, dan sulit dipahami dan dimengerti oleh orang lain di luar budaya yang bersangkutan. Ironisnya sistem pencatatan tari yang lebih mengarah ke deskripsi gerak secara verbal masih dilakukan oleh seniman, bahkan mahasiswa di lingkungan pendidikan tinggi seni sampai sekarang. Tentunya catatan itu hanya bisa diinterpretasikan secara tepat oleh si penulis saja. Kendala ini disebabkan karena belum adanya bahasa yang sama untuk menuliskan gerak antara seniman yang satu dengan seniman yang lainnya. Tidak demikian halnya dalam seni musik, karena telah mempunyai bahasa yang sama untuk mengungkapkan karya mereka secara tertulis melalui notasi musik/notasi balok, sehigga dapat diketahui dan dipertunjukkan kembali secara persis oleh orang lain atau generasi selanjutnya. Mungkinkah seni tari dapat mengalami hal yang demikian? Ini merupakan salah satu masalah yang akan dikemukakan dalam penulisan ini.

Pada tahun 1983, di Jakarta diselenggarakan lokakaryauntukmencarisistempendokumentasian tari dan drama tari tradisi oleh ASEAN. Pada akhir lokakarya para peserta berpendapat bahwa riset dan dokumentasi menempati kedudukan tersendiri, karena ia dapat memberikan bentuk kepada konsep dan pemikiran yang tak teraba.
Informasi yang dapat memberikan identifikasi dan deskripsi tari harus diarsipkan sebagai bahan acuan, penerbitan, kegiatan masyarakat dan program pendidikan serta untuk mempertimbangkan dalam menentukan kebijakan pelestarian sejarah (Murgiyanto, 1992: 160).

Melalui kemajuan teknologi saat ini, menawarkan banyak alternatif untuk mendo kumentasikan tari secara visual, yang tentunya sistem pendokumentasian semacam ini bermanfaat sekali untuk mendukung dan melengkapi dokumentasi tertulis, sehingga jika ada keraguan tentang ketepatan gerak dalam dokumentasi tertulis, bisa dilihat beberapa detik dalam dokumentasi visual. Tetapi teknik perekaman semacam apa yang pas untuk seni tari merupakan permasalahan lainnya dalam penulisan ini.

\section{Pencatatan Tari Sebagai Salah Satu Sistem Pendokumentasian Tari}

Pencatatan dapat ditujukan atau disamakan dengan cara mencatat atau membuat peringatan (Hani, tt: 521). Caranya dapat bermacammacam dengan tujuan dapat diungkap kembali, dibaca, dilihat, disebarluaskan, disimpan, dan sebagainya.

Ada beberapa alasan kenapa kita butuh catatan tari. Pertama, dengan adanya catatan tari kita akan mampu merekam, mendokumentasikan, dan mengawetkan tarian kita saat ini, sehingga generasi mendatang tak perlu susah payah jika akan merekonstruksikannya. Kedua, catatan tari dapat pula berfungsi sebagai komunikasi, karena dengan adanya catatan tari niscaya penyebaran suatu jenis tari dalam dan antar daerah, atau bahkan ke luar negeri akan dapat dilakukan dengan lebih cepat dan cfisien.

Ada yang menyatakan bahwa dengan film atau video tape saja, tari dapat didokumentasikan dengan sempurna. Dalam perkembangan mutakhir bahkan ada pula pendapat dan percobaan bahwa komputer yang merupakan salah satu puncak perkembangan teknologi dewasa ini juga menjanjikan dapat pula berfungsi sebagai alat pencatatan tari yang sempurna (Soedarsno, 1978: 1). Pada kenyataannya jika dikaji secara cermat tidak ada satu pun sistem notasi tari yang sempurna. Jika dibuat sederhana, tidak mampu mencatat gerak yang detail, jika dibuat terlalu 
complicated (dapat menulis semua gerak) cara mencatat dan membaca kembali terlalu sukar dan memakan waktu.

Berbagai sistem yang telah pernah dicipta dan direka oleh para ahli dengan beberapa perkecualian, tidak ada yang digunakan dalam jangka waktu lama dan dipakai oleh banyak orang (Soedarsono, 1978: 1). Pencatatan yang sekarang umum dilakukan di kalangan tradisi adalah dengan menggunakan kata-kata. Ada yang bentuknya sangat sederhana yaitu hanya menyebutkan namanama ragam gerak secara berturutan, tetapi ada pula yang lebih rumit dengan melukiskan posisiposisi anggota badan dari hitungan ke hitungan. Lebih memperjelas ada kalanya pula disertakan gambaran pola lantai. Catatan dengan bahasa verbal semacam ini baik yang sederhana ataupun yang rumit, hanya dapat dipakai oleh kalangan terbatas. Demikian pula jenis tari yang dapat dicatat terbatas pada satu atau dua gaya saja. Sistem yang dipakai antara satu daerah dengan daerah yang lain, bahkan antara satu guru dengan guru yang lain sangat berbeda. Dengan demikian catatan tersebut lebih bersifat untuk memenuhi kebutuhan pribadi dari pada untuk komunikasi (Hutchinson, 1966: 151).

Seminar nasional notasi tari yang diselenggarakan oleh Direktorat Kesenian, Depdikbud di Bandung pada tahun 1978, menawarkan berbagai alternatif tentang sistem pencatatan tari tradisi dari berbagai daerah antara lain Bali, Sunda, dan Jawa yang secara keseluruhan dapat disimpulkan bahwa masing-masing daerah mempunyai cara sendiri-sendiri yang hanya dapat dipahami oleh kalangan terbatas, terutama masyarakat daerah tersebut. Dengan demikian sangat sulit untuk disebarluaskan ke daeah lain. Hal tesebut merupakan suatu kekuranagan bagi teknik pengumpulan dan pencatatan tari tradisional Indonesia, karena belum dikenalnya sistem pencatatan gerak yang umum yang dapat dibaca oleh siapa saja yang telah mempelajarinya.

Ada beberapa sistem/cara pencatatan tari tradisi yang masih dilakukan sampai sekarang. Pencatatan tari yang dilakukan di Jawa Tengah dan Jawa Timur pada umumnya memberikan petunjuk atau keterangan dengan menyebutkan nama-nama gerak atau rangkaian gerak. Contoh pencatatan tari dengan kata-kata yang melukiskan gerak tari dengan perincian segmen-segmen yang digerakkan atau posisinya adalah sebagai berikut:

Lumaksana debeg gejug: kedua kaki lurus berjajar, hitungan satu dan lima kaki andebeg, yaitu tumit tetap menempel di lantai, hanya telapak bagian depan dihentakkan halus (kalau kanan menjadi hitungan satu). Hitungan dua atau enam kaki anggejug yaitu kaki kanan atau kaki kiri jinjit dan diterapkan di belakang kaki yang depan. Hitungan 2-3-6-7 kaki selalu mendhak, hitungan 8 atau 4 kaki mendatar atau anjejer/ lurus (Humardani, 1986:298).

Catatan tari dengan model seperti tersebut di atas ternyata dilakukan pula di Jawa Barat. Sebagai contoh adalah catatan dari tari Sunda yang ditulis oleh M. Suriadirja dan I. Adiwidjaya, mereka berusaha membimbing dengan menyajikan tulisan tentang cara-cara menggerakkan tubuh yaitu:

Bersamaan dengan bunyi gong, kepala bergerak sedikit (gedheg), sekarang kedua tangan diulur ke muka dan dibuat gerakan kecil-kecil menurut irama gendhang dan seterusnya (Benny, 1978: 6)

Sedikit catatan tersebut maka akan timbul beberapa pertanyaan, yang dimaksud sedikit gedheg itu yang seperti apa dan bagaimana. Demikian pula yang dimaksud dengan gerakan yang kecilkecil itu bagaimana dan apa yang digerakkan. Pertanyaan-pertanyaan itu dengan sendirinya muncul dari pembaca yang tidak akrab dengan gerakan atau terminologi dari tari itu. Bagi yang pernah kenal dengan tarian tersebut diharapkan dapat menginterpretasikan catatan itu berdasarkan kemampuan dan pengalamannya.

Kata-kata seringkali tidak cukup jelas untuk mengungkapkan gerak yang dimaksudkan, sehingga sering tidak seimbang antara panjangnya kalimat yang harus disusun dengan pemikiran yang telah dilakukan, dengan hasil yang seringkali kurang tercapai.Catatan tari seperti di atas yang lebih mengarah ke uraian gerak atau deskripsi gerak ternyata sampai sekarang masih tetap dilakukan oleh mahasiswa tari di lingkungan Perguruan Tinggi seni, dengan penambahan pola lantai, iringan, dan tata lampu sebagai pendukung suasana jika memang itu diperlukan. Kelemahan pencatatan ini hanya bisa diterjemahkan oleh si 
penulis/penata tari dan penari yang telah akrab dengan tarian tersebut. Itupun dalam jangka waktu yang terbatas.

Contoh lain adalah catatan tari yang ada di istana Yogyakarta dan yang telah dilakukan oleh tokoh-tokoh tari gaya Yogyakarta dan Surakarta yang sifatnya lebih sederhana dan global dibandingkan dengan contoh yang dikemukakan sebelumnya yaitu:
Punika panut lampahipun Kagungan Dalem Bedhaya enggal yasan dalem ingkang sinuwun kapin VII, Karsa Dalem mundhut cariyosipun kagungan Dalem Serat Babad, nalika Kanjeng Panembahan Senapati Matawis, mangrebasing prang, mangrurah kitha Madiyun. Karsa Dalem gendhing Gandakusuma ndhawah awisawis Gambuh, ladrang, terus ketawang Mijil. Tinengeran kaping 20 Dulkangidah, tahun Jemawal. Sinengkalan: Jalma Nembah Salira Nata.

\begin{tabular}{c|l|l}
\hline Ing ngandhap punika lampahing beksa & Pasindhen & Gangsa \\
\hline$\bullet \quad$ Awit lajur nyembah sedaya & Engge & 2 \\
$\bullet$ Minger majeng ngidul, ngadeg mapan & Senapati & 1 \\
$\bullet \quad$ Ngenceng mawi udhet, nyathok & Ing bang wetan & 2 \\
$\bullet \quad$ Aliyan kiwa nyathok & Kang tingran & \\
..............................dan seterusnya & & \\
\hline
\end{tabular}

Kemudian catatan Beksan Panji Kembar oleh bapak S Ngaliman salah seorang tokoh tari gaya Surakarta sebagai berikut (Ngaliman, 1971: 6).

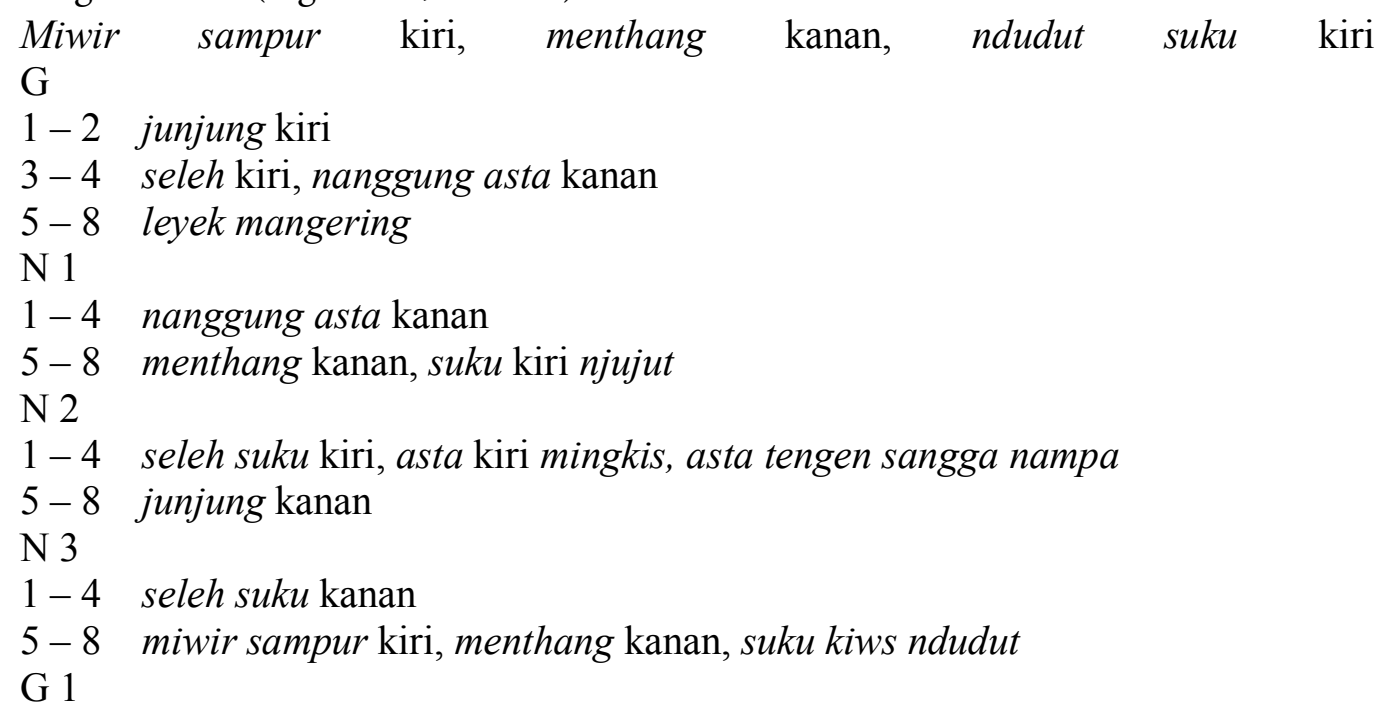

Seorang tokoh tari gaya Yogyakarta yaitu Sasminta Mardawa dalam mendokumentasikan tarinya hampir sama dengan contoh di atas, hanya menambahkan gambaran pola lantai atau gawang yang sering juga disebut rakit untuk tari Bedaya atau Srimpi.

Beberapa contoh pencatatan tari yang dikemukakan di atas cukup dapat dipahami bagi yang pernah mendalami tari gaya tersebut. Tetapi bagi yang belum pernah kenal jelas akan sangat sulit. Orang dapat membaca tulisan tersebut dengan berhasil jika bukan hanya mengetahui aturanaturan membaca, menafsirkannya, melainkan juga mengenal perbendaharaan gerak yang hanya disebut namanya. Meskipun demikian catatan seperti tersebut di atas telah banyak memuaskan kebutuhan sebagian besar seniman tari tradisi.

Berdasarkan contoh-contoh tersebut maka dapat dilihat kelemahan-kelemahan cara pencatatan tari tradisi antara lain: (1) Hanya dapat dibaca oleh seniman/penari yang pernah mempelajari tari itu secara serius; (2) Bersifat sangat global, kurang 
complicated karena banyak yang tidak teraih olehnya, misal hal-hal yang detail dan variasi/ kembangan akan sangat minim kemungkinannya. Karena dalam tari tradisi ada beberapa variasi gerak yang menyangkut arah, level, kualitas, dan volume gerak yang sudah pasti. (3) Hubungan timbal balik antara penulisan dengan praktek tidak seimbang. Semakin lengkap penulisannya, semakin kurang praktis dan efisien, sedangkan semakin kurang lengkap penulisannya semakin dirasakan tidak jelas dan tidak terarah (Supartha, 1986: 285)

Lebih lanjut ditegaskan oleh Humardani bahwa cara pencatatan tari tradisi itu tidak memenuhi tuntutan tari modern/garapan baru di Indonesia yang selalu membuat gerak baru, menggerakkan seluruh segmen tubuh, dan menggunakan kualitas dan kecepatan gerak yang mungkin terjadi pada setiap anggota tubuh (Humardani, 1986: 295). Sebagai sebuah dokumentasi mestinya harus bisa dibaca dan dipahami oleh semua orang yang memerlukan. Dengan demikian para seniman tari di lingkungan Pendidikan Tinggi Seni yang telah mempunyai wawasan cukup luas semestinya mencari alternatif lain dalam mencatat tari agar bisa disebarluaskan ke daerah lain.

\section{Notasi Laban Sebagai Satu Alternatif Sistem Pencatatan Tari}

Jika memalingkan perhatian ke dunia Barat khususnya benua Eropa dan Amerika, maka akan berderetlah sejumlah nama-nama tokoh dengan metode dan sistimatikanya sendiri-sendiri mengenai pencatatan tari. Ada yang metodenya sangat terbatas scope perkembangannya, ada pula yang dianggap paling representatif dapat merealisasi maksud dan tujuan. Nama-nama tersebut di antaranya adalah Thoinot Arbeu dengan bukunya yang berjudul Orchesographie (1588), Beauchams dan Raul Ager Feuillet dengan bukunya yang berjudul Choreographie ou L'Art de Decrire la Danse (1700), Seorang penari dan koreografer Arthur Saint Leon dengan bukunya yang berjudul Stenochoreographie (1852), Albert Zorn ( 1887), Valdimir Stepanov (1892) dan Margaret Morris dengan bukunya Notation of Movement, kemudian Rudolf Laban dengan bukunya yang berjudul Schrifttanz (1928). Sesudah Laban masih ada beberapa penemu sistem pencatatan tari, dan salah satu di antaranya adalah Joan dan Rudolf Benesh dengan bukunya yang berjudul Choreology yang diterbitkan pada tahun 1959 (Hutchinson, 1989: 1-4).

Data tersebut menunjukkan bahwa sebenarnya sejarah notasi tari di Barat telah mulai dirintis sejak abad ke XV. Waktu ke waktu mereka berusaha menyempurnakan kekurangan dari tulisan-tulisan terdahulu, dan sampai sekarang usaha untuk mendapatkan notasi tari yang paling memenuhi persyaratan, yaitu notasi yang dapat mencatat segala jenis dan bentuk gerak serta mudah dibaca oleh siapa saja, masih terus dilakukan. Di Timur (khususnya di Indonesia) seperti yang telah dijelaskan sebelumnya bentuk-bentuk catatan tari juga telah ada, tetapi semuanya lebih merupakan catatan penolong untuk mengingat frase-frase gerak yang hanya dapat dibaca oleh pewaris tradisi yang bersangkutan. Jika pewaris tradisi tersebut telah beberapa generasi, sulit pula bagi pewaris tradisi itu untuk membacanya kembali.

Sebuah notasi yang baik harus betul-betul cermat, tepat, universal, dan mampu merekam detail-detail posisi dan gerak yang paling lembut dan rumit dari setiap bagian tubuh. Masalah utama yang selalu muncul yaitu karena tari adalah seni yang bergerak dalam ruang dan waktu, sehingga dalam sejarah pencatatan tari selalu saja terdapat kelemahan-kelemahan pada notasi yang pernah ada. Gerak dari tubuh manusia di dalam ruang dengan kemungkinan-kemungkinan yang tak terbatas, sangatlah sulit dicatat di atas kertas yang hanya berdemensi dua (Burtner, 1970: 130). Rudolf Laban seorang penari dan koreografer berdarah Austro Hungaria berusaha sepenuh hati mencurahkan sebagian besar dari hidupnya untuk menciptakan sebuah sistem notasi gerak yang bisa mencatat sembarang gerak manusia. Pada awalnya ia memikirkan masalah teori dan bentuk gerak di dalam ruang dan kualitas gerak, tetapi kemudian ia lebih menaruh perhatian pada notasi tari yang akhirnya berhasil dengan diterbitkannya bukunya yang pertama pada tahun 1928 (Hutchinson, 1966: 153).

Sistem notasi yang ditawarkan oleh Rudolf Laban yang telah menyita waktu lebih dari limapuluh tahun hingga sekarang terbukti paling praktis. Kekuatan sistem laban terletak pada baris logika simpelnya dan universalitasnya. Sebuah notasi universal harus berupa notasi yang didasarkan atas kemungkinan-kemungkinan ana- 
tomi tubuh, dan setiap langkah atau gerakan dideskripsikan oleh elemen-elemen dasarnya, bagian tubuh, arah, level, irama, dan lain-lain. Notasi semacam ini akan membuat gerakan apapun menjadi dapat dipahami oleh seseorang yang telah secara seksama mempelajarinya. Kerugian langsungnya adalah karena setiap langkah dan gerak ditulis secara penuh, maka pembaca harus merakit kembali symbol-simbol ke dalam satu gerakan hingga selesai. Apakah proses ini berjalan secara lancar atau membosankan, tergantung pada pengalaman dan kemampuan si pembaca itu sendiri. Seperti halnya dengan jenis bacaan apapun, praktek merupakan syarat yang diperlukan untuk mencapai kelancaran. Seperti halnya seorang pemula yang belajar membaca, maka suku kata akan dibacanya terputus-putus. Tahap awal dalam membaca notasi juga demikian. Langkah dan gerak terputus-putus oleh seorang pemula, bakal segera berubah menjadi pola-pola gerak yang mengalir mulus bila hubungan antara simbol-simbol di kertas dan gerakan-gerakan yang direpresentasikan oleh simbol-simbol tersebut akan segera dipahami secara otomatis. Salah satu keuntungan menggunakan simbol-simbol blok dalam notasi laban adalah bahwa simbol-simbol itu membentuk pola-pola yang mudah ditangkap oleh mata.

Eksperimen pertama penggunaan notasi laban terjadi di Jerman pada tahun 1939, ketika diselenggarakan sebuah kongres tari. Sebelum kongres diselenggarakan diadakan persiapan untuk pementasan sebuah program tari secara besar-besaran. Seribu penari yang ambil bagian dalam pementasan itu tersebar di empatpuluh kota dikirim catatan tari lengkap dengan notasi laban untuk latihan-latihan pendahuluan. Ketika para penari bertemu untuk pertama kali mereka hanya mengkordinasi gerak dan memperhalus koreografi. Dengan cara yang sangat praktis ini berhasillah produksi tari itu di atas pentas dengan hanya sekali dress rehearsal saja (Soedarsono, 1978:361). Sejak saat itu notasi laban tersebar hingga mencapai Tibet Timur di mana catatan tari-tarian rakyat Tibet banyak ditulis dengan notasi laban. Demikian juga di Cekoslovakia, Hongaria, dan lain-lain. Diharapkan suatu saat semua materi tari yang ada akan ditulis dalam notasi laban sehingga dapat dipelajari oleh semua orang (Hutchinson, 1966:154).
Dance Notation Bureau yang merupakan pusat pencatatan tari yang di dirikan di New York pada tahun 1940, nampaknya merupakan lembaga yang paling gigih dalam usaha penyebarluasan dan penyempurnaan notasi laban. Tokoh dari lembaga ini yaitu Ann Hutchinson telah berhasil menyempurnakan dan memperluas notasi laban yang sejak tahun 1959 telah disepakati keseragaman dan penggunaan notasi laban untuk seluruh dunia (Hutchinson, 1966: 154).

Dalam mempelajari notasi laban sebenarnya tidak terlalu sulit, asal ditempuh jalan seperti pada waktu kita belajar membaca dan menulis. Pertama kita membaca dan menulis kata yang sederhana, kemudian melangkah membuat kalimat pendek, sampai akhirnya membuat kalimat yang panjang dan kompleks. Apa yang esensial bagi seorag pembaca dan penulis score notasi adalah bukan kemampuan mempelajari satu sistem notasi, melainkan kemampuan menganalisis gerakannya.

Simbol notasi laban hanya terdiri dari 9 yang berbentuk pictorial dan menunjukkan direksi atau arah gerak. Sistem pencatatan notasi laban menggunakan kolom-kolom yang jumlahnya tergantung dari kompleksitas gerak yang dicatat, tetapi jika sudah mahir menggunakan notasi laban tidak perlu menggunakan kolom-kolom yang terlalu banyak, tetapi minimal menggunakan tiga kolom pokok. Beberapa hal penting yang harus diketahui dalam mempelajari notasi laban adalah (1) Simbol yang merupakan huruf dari bahasa gerak menunjukkan arah dan level dari bagian tubuh yang digerakkan; (2) Pencatatan gerak dititikberatkan pada arah atau tujuan gerak misalnya maju, mundur, kanan, kiri, serong depan kiri, serong depan kanan, berputar ke kanan, berputar ke kiri, dan sebagainya; (3) Tubuh manusia secara garis besar dibagi menjadi dua yaitu bagian kanan dan bagian kiri, yang masing-masing dibagi lagi menjadi bagian-bagian dari anggota tubuh sepeti kaki, tungkai, pinggang, dada, lengan, tangan, kepala, dan sebagainya; (4) Pencatatan notasi laban dilakukan dan dibaca dari arah hadap penari; dan (5) Notasi laban dibaca dan ditulis dari bawah ke atas, dan dilanjutkan ke kanan. 
Simbol-simbol arah dalam notasi laban:

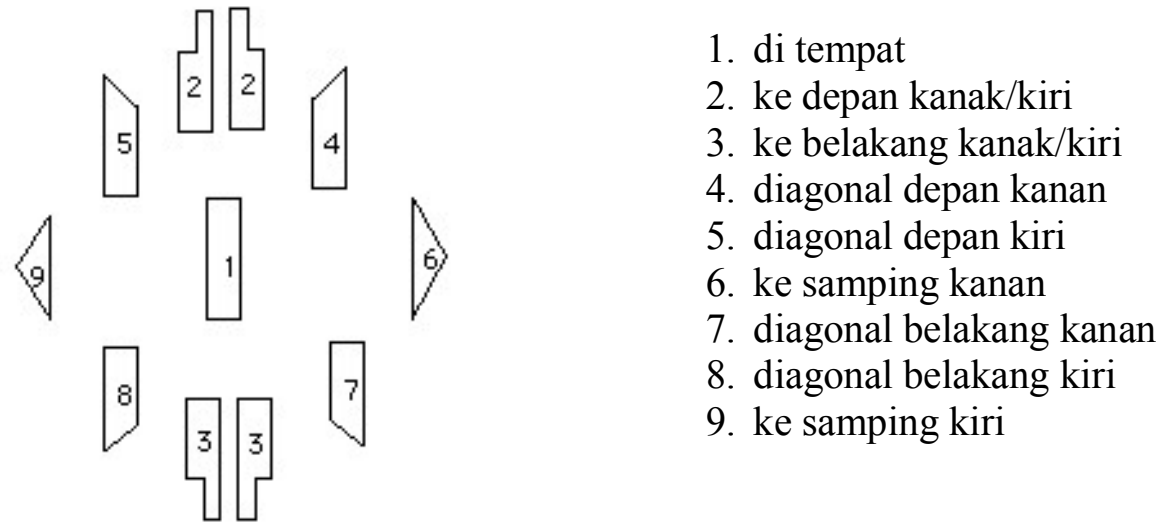

Simbol-simbol arah tersebut dapat dibedakan menjadi tiga level yaitu: level rendah, level sedang dan level tinggi

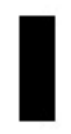

level rendah

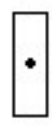

level sedang

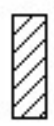

level tinggi

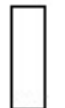

Timing gerak dalam notasi laban ditunjukkan dengan panjang dan pendeknya simbol arah

Untuk menunjukkan bagian tubuh mana yang bergerak, dalam notasi laban dijelaskan dengan pra simbol yang penulisannya diletakkan sebelum simbol arah. Beberapa contoh pra simbol dalam notasi laban antara lain :

$\begin{array}{ll}\text { C } & \text { kepala } \\ \text { 目 } & \text { torso } \\ \text { ㅊ․ } & \text { lengan atas } \\ \text { A } & \text { lengan bawah } \\ \text { 非 } & \text { tangan } \\ \text { 悲 } & \text { jari tangan }\end{array}$


contoh pencatatan gerak dengan notasi laban:
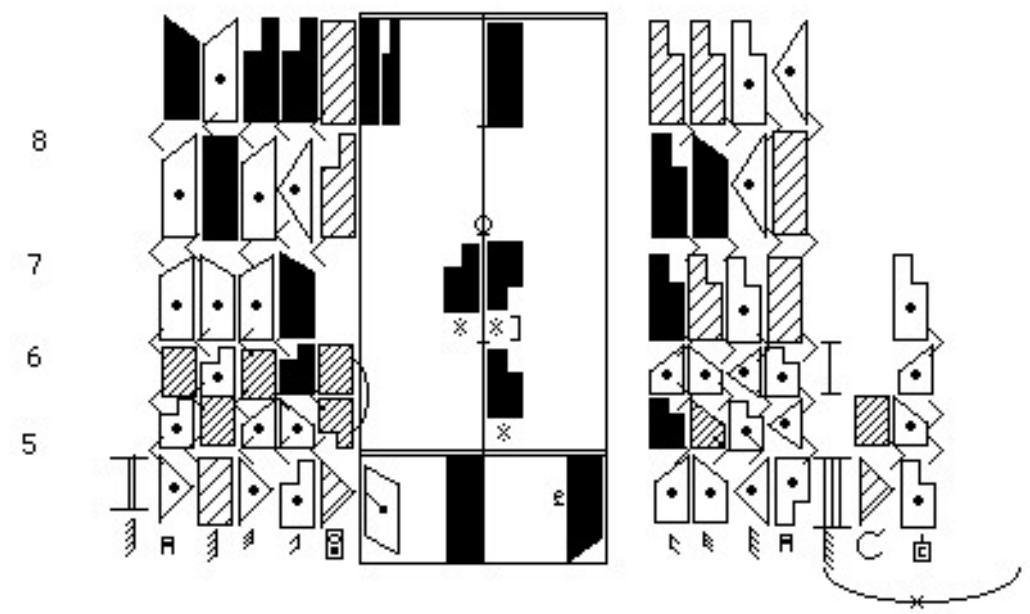

Sepertiyang telah dijelaskan sebelumnyabahwa notasi laban telah tersebar dan diakui di seluruh penjuru dunia. Notasi laban juga merupakan mata pelajaran resmi di Universitas-universitas seluruh Amerika yang mempunyai jurusan tari atau pendidikan jasmani, demikian halnya di Eropa (Hutchinson, 1966: 162). Notasi laban di Indonesia juga diajarkan di seluruh Pendidikan Tinggi seni, bahkan di tingkat sekolah menengah (SMKI) juga sudah dikenalkan. Sayangnya para mahasiswa banyak yang menganggap mata pelajaran tersebut hanya sekedar apresiasi belaka, sehingga perlu pemikiran lebih lanjut agar mahasiswa merasakan manfaat dan kegunaannya, kemudian mengembangkannya. Memang diakui oleh banyak orang bahwa mempelajari notasi laban yang lengkap dan rumit diperlukan ketekunan, ketelitian, dan analisis yang tepat untuk menulis dan membacanya. Barangkali itulah salah satu faktor yang menghambat mahasiswa tidak begitu tertarik untuk mendalami dan memahaminya.

Dalam seminar notasi tari I pada tahun 1978, telah disepakati bersama untuk menggunakan notasi laban sebagai keperluan notasi tari kita. Pilihan jatuh pada notasi laban karena di antara sistem-sistem yang ada, sistem notasi laban adalah yang paling mampu merekam tari-tari kita dan paling luas digunakan di dunia tari (Murgiyanto, 1993: 34). Dengan demikian jika para seniman dari pendidikan tinggi seni yang tersebar di seluruh Indonesia mampu dan mau memanfaatkan notasi laban ini, maka tidak mustahil jika suatu saat kelak notasi laban menjadi bahasa komunikasi tari di Indonesia.

Secara tegas Ben Suharto mengemukakan bahwa notasi laban yang lengkap, teliti, dan mantap itu masih memerlukan waktu lama dan ketekunan khusus untuk bisa direalisasikan pelaksanaannya di Indonesia. Beliau lebih cenderung untuk memanfaatkan apa yang ada (sistem pencatatan tari tradisi) yang dianggap praktis dan memenuhi kebutuhan terutama oleh para seniman tradisi, sehingga sistem itu perlu terus dibina dan dikembangkan. Jika perlu diadakan workshop di daerah-daerah dalam unit yang kecil dulu untuk berusaha menjaring sebanyakbanyaknya cara pencatatan tari yang ada, untuk kemudian dituangkan dalam sebuah cara pencatatan tari yang lebih lengkap dan diusahakan untuk disebarluaskan.Namun demikian, melihat kemajuan yang ada sejak penggunaan notasi laban disepakati di Indonesia pada tahun 1978, seharusnya kita merasa optimis bahwa suatu saat notasi laban betul-betul bisa menjadi bahasa komunikasi tari di Indonesia, terutama di lingkungan akademik.

\section{Audio Visual Sebagai Pelengkap Catatan Tari}

Sistem pendokumentasian tari melalui perekaman gerak secara visual tentunya sangat bermanfaat sekali untuk mendukung dan 
melengkapi dokumentasi tertulis. Jika ada yang beranggapan bahwa film dapat menggantikan tugas catatan tari, atau yang berpandangan bahwa film meniadakan keharusan pemakaian catatan/notasi tari, dan anggapan bahwa film lebih mudah untuk mendokumentasi dan merekonstruksi tari, sebenarnya anggapan itu terlalu dilebih-lebihkan. Pandangan semacam itu barangkali dikemukakan karena belum pernah berkesempatan mengkomparasikan keuntungan dan kerugian dari kedua metode tersebut.

Kalaukitamengamatisebuah rekaman tari,yang kita lihat adalah sederetan sekwen-sekwen yang disusun dari potongan film. Sesaat dari samping, dari depan, dari atas, dan seterusnya. Sebuah frase gerak dapat saja dipotong-potong, sebagian di temple di sini, sedang bagian yang lain diletakkan pada bagian lainnya untuk mendapatkan kesan dramatis tertentu. Menamakan film semacam ini sebagai sebuah rekaman tari, sangat tidak masuk akal. Apalagi untuk menyamakan dengan sebuah tarian. Sebab sebuah tarian harus merupakan satu kesatuan yang utuh, jika tidak maka tidak bisa disebut sebagai tari. Sebuah rekaman untuk dokumentasi harus apa adanya, tepat, teliti, tanpa ada tambahan-tambahan (Murgiyanto, 1993: 34).

Dalam pengambilan gambar, seorang kameramen ada kalanya berusaha untuk mencapai hasil yang memiliki daya tarik artistik, sehingga seringkali harus mengambil gambar dengan teknik tertentu agar indah untuk dinikmati. Rekaman semacam itu tidak menjanjikan satu catatan yang akurat mengenai bentuk tari yang orisinil.

Scbuah film/audio visual yang sengaja dibuat sebagai dokumentasi tari seharusnya tidak ditangani oleh seniman sinematografi atau cameramen yang suka mempermainkan angle shot, close up, close shot, medium shot, knee shot, dan lainnya, tetapi dibutuhkan seorang cameramen teknis yang bersedia meletakkan kameranya pada satu titik, dan membiarkan beroperasi begitu saja (Murgiyanto, 1993:34). Pengambilan close up, angle shot, dan sebagainya dari seorang cameramen, meskipun sesaat akan menyebabkan hilangnya sebuah rangkaian gerak dari tari secara keseluruhan. Akan lebih menguntungkan jikan diambil dengan full shot sehingga dapat terambil lengkap dari satu adegan/gerakan. Jika akan mengambil detailnya gerak dari bagian anggota tubuh tertentu yang dirasa penting, barangkali bisa menggunakan teknik spilt screen dengan dua kamera. Kamera yang satu mengambil dari jarak jauh, dan kamera lain mengambil dari jarak dekat dari bagian tubuh yang dikehendaki.Efeknya aka nada dua gambar dalam satu layar, separo memuat gambar penari secara keseluruhan, sedangkan separonya lagi memuat gerak bagian tubuh tertentu (keduanya bergerak bersama), sehingga tidak akan kehilangan struktur tari secara keseluruhan (Latif, 1986). Dengan demikian rekaman tari untuk sebuah dokumentasi tidak ada sangkutpautnya dengan sinematografi.

Keuntungan dokumentasi dengan audio visual/film ini adalah orang dapat memperoleh gambaran visual secara keseluruhan serta gaya dari sebuah produk tari yang selesai berikut wujud pemanggungan, pengaturan pentas, ekspresi, dan sebagainya. Sedangkan kekurangannya pertama adalah menyangkut vinansial, untuk membuat rekaman yang baiksudah barang tentu memerlukan banyak biaya karena harus menyediakan special lighting, studio yang cocok, para cameramen, dan sebagainya.Kesulitan-kesulitan yang lain dalam mempelajari dokumentasi audiovisual ini adalah ketika akan menganalisis bagian gerak tertentu secara seksama akan menemukan kesulitan, karena slow motion di layar berarti akan kehilangan tempo irama yang sesungguhnya.

Bagaimanapun audio visual/film sangat bermanfaat untuk melengkapi notasi tari sebagai sarana untuk menganalisis gerak dan mengawetkan koreografi. Demikian sebaliknya notasi tari akan akan lebih mudah dipahami jika dilengkapi dengan rekaman gerak, Satu dan lainnya saling berkaitan dan melengkapi, tetapi tidak bisa salig meggantikan.

\section{Penutup}

Melihat akan kemajuan perkembangan bidang ilmu pengetahuan dewasa ini menghendaki adanya cara atau metode pencatatan tari sebagai sebuah dokumentasi untuk mendukung penyebarluasan yang lebih mantap, karena untuk kepentingan generasi mendatang, catatan/notasi tari dapat membantu memperkaya literatur, dan pengawetan koreografi.

Notasi laban yang telah dipakai di kalangan dunia secara luas ternyata memenuhi syarat untuk mencatat tari-tarian di Indonesia, dan 
telah disepakati bersama penggunaannya untuk keperluan notasi tari kita. Meskipun banyak kendala yang akan dihadapi untuk merealisasikan gagasan tersebut, tetapi setidaknya dengan melihat kemajuan yang dicapai dengan semakin bertambah banyaknya bentuk-bentuk tari yang ditulis dengan notasi laban, dunia tari di Indonesia optimis bahwa suatu saat notasi laban bakal menjadi bahasa komunikasi tari di Indonesia. Itu perlu adanya jalinan kerjasama dari pihak yang berwenang untuk terus menerus mendukung terealisasinya kesepakatan tersebut.

Langkah selanjutnya perlu dirangsang para seniman-seniman tari hususnya di lingkungan akademik untuk biasa membaca dan menulis tari dengan notasi laban, sehingga diharapkan tidak terlalu lama notasi laban dipakai sebagai sarana komunikasi dan pertukaran informasi tentang tari-tarian yang ada di Indonesia

Audio visual/film tari dapat melengkapi sebuah notasi tari, tetapi tidak dapat menggantikan peranannya secara penuh. Satu sama lain saling mendukung utuk kelengkapan dan kesempurnaan sebuah dokumentasi. Karena hanya mengamati sebuah rekaman tari saja kemudian merekonstruksikan kembali ternyata jauh lebih sulit daripada membaca sebuah notasi tari.

\section{Kepustakaan}

Beny, C.J. 1978. "Cara-cara Pencatatan Tari Di Jawa Barat", Makalah disampaikan pada Seminar Notasi Tari oleh Direktorat Kesenian, Bandung: Departemen Pendidikan dan Kebudayaan.

Boas, Franziska. 1972. Fungction of Dance in Human Society, New York: Dance Horizons.

Burtner, Elizabeth. 1970. "Dance Notation Makes Legend Into History" dalam The Dance Experience, editor Miron Howard Nadel dan Constance Owen Nadel, New York: Praeger Publisher.
Departemen Pendidikan dan Kebudayaan, 1990. Kamus Besar Bahasa Indonesia, Jakarta: Sinar Harapan.

Humardani, S.D. 1986. "Cara-cara Pencatatan Tari di Kalangan Tari Tradisi di Jawa Tengah", dalam Pengetahuan Elementer Tari dan Beberaopa Masalah Tari, Jakarta: Direktorat Kesenian, Proyek Pengembangan Kesenian, Departemen Pendidikan dan Kebudayaan.

Hutchinson, Ann. 1966. "The Preservation of The Dance Score Through Notation" dalam The Dance Has Many Faces, editor Walter Sorell, New York and London: Columbia University Press.

1989. Labanotation The Sistem of Analyzing and Recording Movement, New York: Theatre Arts Books.

Latif, Halilintar. 1986. "Komposisi Tari Untuk Televisi”, Skripsi untuk menempuh gelar Sarjana pada lingkungan Fakultas Kesenian ISI Yogyakarta.

Murgiyanto, Sal. 1992. "Dokumentasi dan Riset Tari: Dunia dan Kita”, dalam Seni Pertunjukan Indonesia, Surakarta: MSPI/STSI Press. 1993. Ketika Cahaya Merah Memudar, Jakarta: Deviri Ganan.

Ngaliman, S. 1971. "Catatan Beksan Panji Kembar”, Solo: Yayasan Senopaten.

Sedyawati, Edi. 1981. Pertumbuhan Seni Pertunjukan, Jakarta: Sinar Harapan.

Supartha, I, Gst, A.Ngr. 1986. "Pencatatan Tari Tradisi di Bali" dalam Pengetahuan Elementer Tari dan Beberapa Masalah Tari, Jakarta: Direktorat Kesenian, Proyek Pengembangan Kesenian, Departemen Pendidikan dan Kebudayaan.

Trimo, Sujono. 1978. Pengantar Ilmu Dokumentasi, Bandung: Remaja Karya. 